\title{
Outline of Ecological and Economic Problems Associated with Low Emission Reductions in Poland's Lubuskie Voivodeship
}

\author{
Maciej Dzikuć ${ }^{1 *}$, Piotr Kułyk ${ }^{1,}$ Maria Dzikuć $^{1,}$ Stanisław Urban ${ }^{1}$, Arkadiusz Piwowar ${ }^{2}$ \\ ${ }^{1}$ Faculty of Economics and Management, University of Zielona Gora, Zielona Gora, Poland \\ ${ }^{2}$ Faculty of Engineering and Economics, Wroclaw University of Economics, Wroclaw, Poland
}

Received: 19 October 2017

Accepted: 18 January 2018

\begin{abstract}
According to estimates by the World Health Organization, approximately 44,000 people die prematurely each year in Poland due to excessive air pollution. The European Commission brought a lawsuit against Poland to the European Court of Justice in Luxembourg in 2015 for failure to comply with EU air quality legislation. Due to poor air quality, Poland has been threatened with penalties that could reach $€ 1$ billion. Although Poland has managed to significantly reduce emissions from industrial plants, a very serious problem with low emissions persists. This article aims to identify the main sources of low emissions in Lubuskie Province and to indicate the environmental benefits resulting from the modernization of the central heating system, involving the replacement of boilers. The article points out that reducing low emissions from boilers in private houses, due to its significant share in air pollution and the fact that this is an underreported problem, could bring a significant positive ecological effect. Analysing the issue from an economic viewpoint, it should be noted that replacing inefficient coal-powered boilers so far provides the largest ecological effect in relation to the investment costs.
\end{abstract}

Keywords: ecology, economy, GHG savings, low emission, Poland

\section{Introduction}

Low emission is the air pollutants introduced into the atmosphere to a height ceiling of $40 \mathrm{~m}$. Obsolete coalfired boilers contribute largely to the formation of low emission, in which the fuel is burned in an inefficient way [1]. Household boilers often use cheap coal, which is dirty and with low heating parameters. In areas inhabited by people materially poorer, an additional problem is the phenomenon of combustion of heating waste in domestic

*e-mail: m.dzikuc@wez.uz.zgora.pl stoves. Moreover, the main low-emission sources should include car transportation [2-3]. This problem particularly applies to older cars that do not meet environmental standards of currently produced cars. Smaller industrial plants also contribute to the formation of low emission. It should be noted that low emission occurs most often almost directly on the ground of $10 \mathrm{~m}$ to the ceiling. This is the reason for a particular hazard for people living nearby, as emissions introduced into the atmosphere at low altitude gather around the places of their emergence. This is the case especially in calm weather. Poor air quality has a negative impact on human health [5-6], and as stated previously, air pollution contributes to 
the premature death of some 44,000 Poles annually [4]. Contaminated air also affects plants, some of which are used for food production [7-8].

Against Poland, the European Commission brought a lawsuit in 2015 for failure to comply with EU air quality legislation to the European Court of Justice in Luxembourg. Due to poor air quality, Poland is threatened with penalties that could reach $€ 1$ billion. It should be emphasized that Poland is currently facing a solution to the problems which in most EU countries have not existed for decades (the "Great Smog" of London took place in 1952 [9]). An important reason for poor air quality in Poland is so-called low emission, which comes mainly from household stoves and local coal-fired boilers. The contamination of communication (especially in large cities) and industrial pollution will also contribute to the formation of low emission [10].

This article aims to identify the main sources of low emission in Lubuskie Voivodeship and to indicate the environmental benefits resulting from the modernization of central heating systems involving the replacement of boilers. The article points out the importance of reducing low emission from boilers in private houses, due to its significant share in air pollution and the fact that this is one of the most underreported problems in Poland.

\section{The Problem of Low Emissions in Lubuskie Voivodeship}

Polish households in urban and rural areas are characterized by a different structure of fuel consumption for space heating. Primarily network heat is used for this purpose in the city, where it warms $59.9 \%$ of dwellings, and natural gas (11.5\%) and solid fuel less than $30 \%$ of households. In the countryside solid fuels predominate, where they are used in almost $90 \%$ of households, the heat from the network warmed only $4 \%$ of apartments, and natural gas $6.2 \%$. The structure of fuels used for heating water also differed substantially. 38.5\% of households located in the city have used for this purpose district heating, natural gas 34.9\%, 19.1\% electricity, and less than $10 \%$ solid fuels. In the countryside the district heating hot water was obtained by only $3 \%$ of households, while $11.8 \%$ of households consumed for this purpose natural gas, $32.7 \%$ electricity, and about 50\% solid fuel [11]. This structure of fuel consumption causes the air quality in less densely populated areas to be even worse than in cities. It should be noted that the statistics do not include combustion in the boiler of household waste, which is often burned in the countryside due to the greater amount of the boiler room of the old type, where waste incineration is technically possible [12-13]. National data should be supplemented with information from Lubuskie Voivodeship. In 2014 one person using the gas network in the country accounted for up to 9 people in the city [14].

Lubuskie is located in the central-western part of Poland, occupying an area of $13,987.88 \mathrm{~km} 2$. The province has a small area on the background of the country, the share of which in relation to the surface of Poland amounts to $4.47 \%$ [15]. The average annual temperature is about $8^{\circ} \mathrm{C}$. The region is one of the warmest in the country. The population 1,011 million, approx. 36\% of which live in rural areas [16].

Lubuskie Voivodeship has the largest forest cover in the country, reaching $49 \%$ of its area [17] - mainly pine. This information indicates that Lubuskie is a place where the air should not be contaminated due to the low share of industry, relatively low count of inhabitants per $1 \mathrm{~km}^{2}$ on the background of the country, or the country's largest share of forests in total area of the province. However, due to the air pollution, which mainly comes from residential space heating in many places in the voivodeship, there is a problem with air quality.

The measurements of emissions to the atmosphere in Lubuskie in 2013-2014 showed that a major problem in air pollution is too high concentrations of particulate matter PM10, which took place in the vicinity of the six surveyed areas. An additional problem was exceeding the allowable arsenic in PM10 matter in the area of three of the six zones in the voivodeship [18].

Analysing the data contained in Table 1, it should be noted that a decrease in emissions of PM10 was greatly affected by the category of combustion processes outside the industry. Although it was not the largest percentage drop, the reduction of PM10 emissions in 2014 in relation to 2013 amounted to $10546.3 \mathrm{Mg}$. A smaller but also significant decrease in emissions of particulate matter in the analysed period was recorded in the category of combustion processes in the production and transformation of energy. It should be emphasized that the total national emissions of PM10 did not reflect the category of forest fires, which is difficult to estimate. The data in Table 1 apply to the whole Poland, but Lubuskie has a similar structure of air pollution and low emission, which is derived mainly from the category of combustion processes outside industry and road transport - the dominant share in the total emissions of PM10 (Table 1).

The spatial distribution of air pollutant emissions in Lubuskie is not uniform. The largest amounts of pollutants are emitted in the areas of districts densely populated and industrialized. Low emission is a major problem in cities and suburban areas where there is a large number of single-family houses. Household boilers, especially coal, contribute to emissions that affect air quality reduction. The size of the low emissions is difficult to estimate. Its share is usually from a few to several percent of the total emissions in areas where there is a heating network. However, in places where there is no heating network, the share of low emission reaches tens of a percent. It should be emphasized that the problem of low emission also applies to rural areas, where there is not only a lack of heating network, but also they do not always have access to natural gas, which contributes to a much larger share of household boiler rooms powered by coal. A huge problem not only in Lubuskie, but throughout the country, is the quality of fuel used for heating. Very often 
Table 1. Emissions of PM10 in 2013-2014.

\begin{tabular}{|c|c|c|c|}
\hline \multirow{2}{*}{ Emission source } & \multicolumn{3}{|c|}{ Emissions of PM10 } \\
\cline { 2 - 4 } & $\begin{array}{c}2013 \\
\mathrm{Mg}\end{array}$ & $\begin{array}{c}2014 \\
\mathrm{Mg}\end{array}$ & $2014 / 2013$ \\
\hline Combustion processes outside industry & 123350.1 & 112803.8 & $91.45 \%$ \\
\hline Combustion processes in the production and transformation of energy & 23267.7 & 21586.4 & $92.77 \%$ \\
\hline Combustion processes in industry & 18521.1 & 18888.5 & $101.98 \%$ \\
\hline Production processes & 18685.2 & 18943.1 & $101.38 \%$ \\
\hline Extraction and distribution of fossil fuels & 7145.2 & 6857.4 & $95.97 \%$ \\
\hline The use of solvents and other products & 1673.9 & 1417.4 & $84.68 \%$ \\
\hline Road transport & 21495.4 & 20904.1 & $97.25 \%$ \\
\hline Other vehicles and equipment & 9521.7 & 9186.5 & $96.48 \%$ \\
\hline Waste management & 12191.5 & 11298.7 & $92.68 \%$ \\
\hline Agriculture & 10380.5 & 10607.9 & $102.19 \%$ \\
\hline Total & 153.7 & 298.6 & $194.27 \%$ \\
\hline
\end{tabular}

Source: [19]

the fuel is coal, which when burned releases a large part of the harmful substances that represent a significant share of the total low emission in Poland. Very often individual boilers burn coal of low quality, which should be treated as a fuel in installations with efficient exhaust gas cleaning systems. Due to the fact that the flue gas cleaning installations are economically inefficient for small boilers in private houses and there is no obligation to install such exhaust gas cleaning systems, such systems practically do not exist in domestic boilers.
The problem in rural areas, in the context of low emissions, is not only the low quality of fuels used in home boiler houses but also the incineration of hazardous waste by farmers. According to research, there is still low awareness among farmers about the impact of waste incineration on human health and the environment [20]. The problem in terms of low emissions in rural areas is also burning leaves, grass burning, and residual straw and other crop residue.

Table 2. Emissions of dust and gas by companies especially aggravating the environment in 2004-2014.

\begin{tabular}{|c|c|c|c|c|c|c|}
\hline \multirow{2}{*}{ Years } & \multicolumn{3}{|c|}{ Emission of dust } & \multicolumn{2}{c|}{ Emissions of gaseous pollutants } \\
\cline { 2 - 7 } & $\begin{array}{c}\text { Lubuskie } \\
\text { (Mg/year) }\end{array}$ & $\begin{array}{c}\text { Poland } \\
(\mathrm{Mg} / \text { year })\end{array}$ & $\begin{array}{c}\text { The share of companies from } \\
\text { Lubuskie } \\
(\%)\end{array}$ & $\begin{array}{c}\text { Lubuskie } \\
\text { (Mg/year) }\end{array}$ & $\begin{array}{c}\text { Poland } \\
(\mathrm{Mg} / \text { year })\end{array}$ & $\begin{array}{c}\text { The share of companies from } \\
\text { Lubuskie } \\
(\%)\end{array}$ \\
\hline 2004 & 3100 & 123200 & $2.5 \%$ & 2110600 & 213613800 & $1.0 \%$ \\
\hline 2005 & 2800 & 110500 & $2.5 \%$ & 2189300 & 213706200 & $1.0 \%$ \\
\hline 2006 & 2500 & 102500 & $2.4 \%$ & 2214900 & 223353900 & $1.0 \%$ \\
\hline 2007 & 1600 & 94800 & $1.7 \%$ & 2019100 & 223269500 & $0.9 \%$ \\
\hline 2008 & 1400 & 76800 & $1.8 \%$ & 1842300 & 216319000 & $0.9 \%$ \\
\hline 2009 & 1400 & 61700 & $2.3 \%$ & 1952400 & 203125600 & $1.0 \%$ \\
\hline 2010 & 1400 & 62500 & $2.2 \%$ & 2080900 & 216155400 & $1.0 \%$ \\
\hline 2011 & 1300 & 57500 & $2.3 \%$ & 2089600 & 220928000 & $0.9 \%$ \\
\hline 2012 & 1200 & 52400 & $2.3 \%$ & 2054200 & 216513700 & $0.9 \%$ \\
\hline 2013 & 1100 & 49500 & $2.2 \%$ & 2009500 & 217492000 & $0.9 \%$ \\
\hline 2014 & 1000 & 47400 & $2.1 \%$ & 2009100 & 209067300 & $1.0 \%$ \\
\hline
\end{tabular}

Source: [13] 
The amount of dust pollution from plants that are particularly harmful to the environment has been greatly reduced in recent years. Analysing the data contained in Table 2, it should be noted that the problem is still gaseous pollutants that were managed to be reduced only slightly. It should be emphasized that the emissions of dust and gas by plants particularly burdensome is not evenly distributed across the country. Lubuskie Voivodeship is characterized by lower levels, especially of gaseous emissions in relation to the surface of the province or living population. The area of the voivodeship is 13.988 thousand $\mathrm{km} 2$, which, with the surface of Poland (312.7 thousand of $\mathrm{km} 2$ ) is less than $4.5 \%$ [21]. However, the share of population of Lubuskie in 2014 amounted to less than 2.7\% (1020 thousand in Lubuskie and 38479 thousand in Poland) [22].

Lubuskie Voivodeship, like the rest of Poland, is characterized by the growth of low emission in the heating season. Analysing the problem of low emission in the region of Lubuskie it is impossible not to mention the pollutants that are emitted by road transport. This applies particularly to cities and roads with heavy traffic. During the combustion of fuels in automobile engines the gaseous components leak into the atmosphere (mainly nitrogen oxides, carbon monoxide, aromatic hydrocarbons). Another problem of Lubuskie is transit traffic. The places with elevated levels of nitrogen dioxide emissions coincide with the course of the A2 motorway (east-west), which in the voivodeship is part of the Berlin-Warsaw route. An increased level of nitrogen

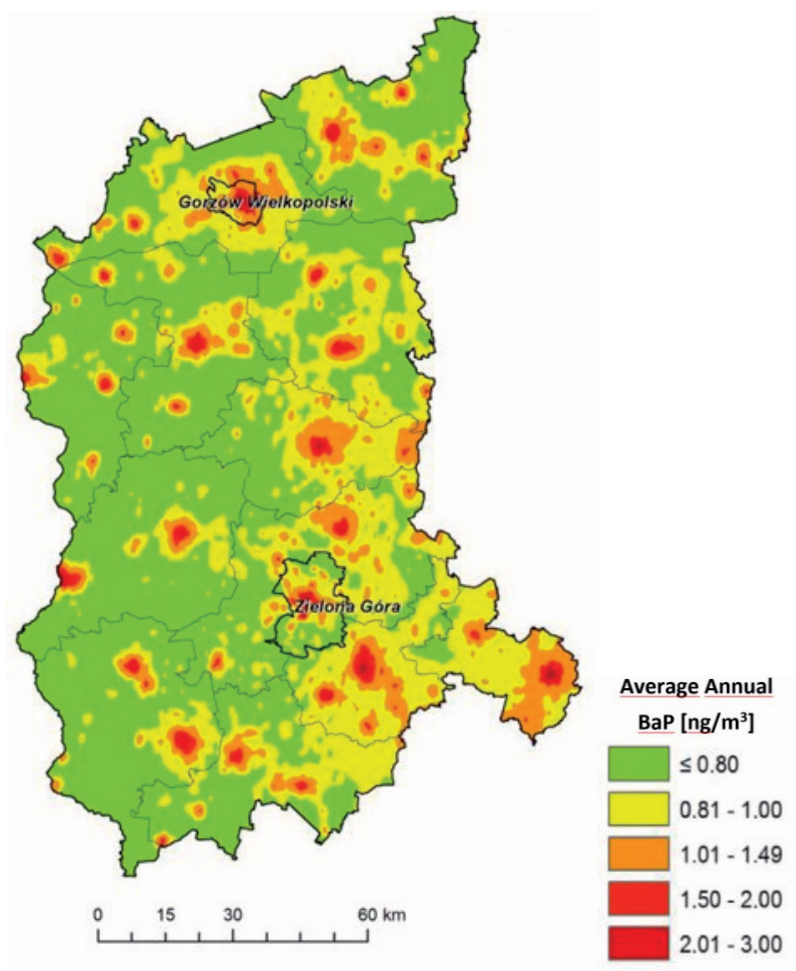

Fig. 1. Distribution of the concentration of benzo(a)pyrene contained in particulate matter PM10 in Lubuskie (2015) . Source: [23] dioxide emissions also takes place near Road S3 (northsouth). Voivode authorities and those of various cities in the region will have to consider a ban on entry of older cars to the cities that do not meet current environmental standards. Similar solutions have been successfully used for many years in many cities in the EU.

An important substance, which is a component of PM10 [24-25], which significantly pollutes the air, is benzo(a)pyrene [26]. The data from 2015 indicate exceeding the target level of benzo(a)pyrene $\left(1 \mathrm{ng} / \mathrm{m}^{3}\right)$. Due to this, all zones in Lubuskie were classified as class $\mathrm{C}$, which causes the need to develop air protection programmes for this area (Fig. 1).

\section{The Possibility of Low Emission Reduction in Lubuskie Voivodeship}

Reducing the level of low emission in Lubuskie requires a range of actions at various levels. Due to the fact that a significant part of the low emission is the air pollution generated during the heating of homes (including single-family houses), the main burden of prevention activities should be directed at buildings inefficient in energy coal-fired boilers [27].

It should be noted that in Lubuskie Voivodeship there are solutions allowing for thermal modernization of public buildings. An example of such support may be funding by the Lubuskie Regional Operational Programme (Priority Axis 3 - Low-carbon economy). The amount dedicated for the implementation of the projects is $€ 10$ million. Their objective is to reduce emissions and the consumption of fossil fuels [28]. The projects are supposed to include the thermal modernization of public buildings. A significant part of the projects also included the exchange of boilers used for heating, and some of the applicants also planned to use the plants based on renewable energy sources [29]. In order to receive support the projects must meet a number of conditions, e.g., reducing $\mathrm{CO}_{2}$ emissions by at least $30 \%$ in relation to the existing system, significantly improving energy efficiency, and providing system monitoring and energy management. It should be noted that the support may be granted only to projects that involve the installation of heating appliances fuelled by sources other than carbon ${ }^{1}$. However, efforts to reduce low emission, formed during the heating of buildings (including single-family dwellings) are rare.

An interesting solution that can significantly contribute to the reduction of low emissions in Lubuskie is funding the replacement of old coal stoves for heating houses. The problem is that this is only the first solution of its kind in Lubuskie, which was passed in October 2016 by the Council of the City of Żary (in the southwestern part of Lubuskie Voivodeship). The residents of Żary, who decide on the liquidation of coal stoves, can get

This knowledge was acquired during the evaluation of applications by one of the co-authors of this article. 
financial assistance of up to $€ 2300$. Unfortunately, the amount planned for this task (about $€ 50,000$ ) will only allow for the exchange a few dozen old household coal stoves. Nevertheless, this is a step in the right direction and this type of solution should be implemented by other cities in Lubuskie.

Analysing the possibility of low emission reduction in Lubuskie, it should be emphasized that the greatest ecological effect can be achieved with the total liquidation of the old coal boiler and connecting the building to the district heating network or by using electric heating and heat pumps with the installation of a gas boiler. These measures may be more effective if both buildings are subjected to thermal modernization [30].

However, the elimination of coal-fired boilers and connection of buildings to the district heating network is not always possible due to the lack of this type of installation in rural or less densely populated urban areas. Therefore, it is necessary to consider replacing old energy inefficient coal-fired boilers with more modern ones, which will have a smaller impact on the environment. Choosing the right, less aggravating environmental installation used to heat buildings can be supported by life cycle assessment (LCA) technique [31-34].

LCA indicates environmental hazards, helping to choose an eco-efficient installation and it is still at the stage of deciding on the heat source [35-37]. LCA has been described by the International Committee for Standardization in the standards series ISO 14040: PNEN ISO 14040:2009 [38] and PN-EN ISO 14044:2009 [39]. The results of LCA (Table 3) are expressed in ecoindicator points $(\mathrm{Pt})$, where $1 \mathrm{Pt}$ of eco-indicator is the value representing one-thousandth of the annual burden on the environment attributable per capita in Europe [40].

LCA is characterized by a certain type of limitation that forms the limits of the system for the analysed heat sources [41-42]. The results presented in Table 3 include the production of a specific unit of heat energy

Table 3. Operating parameters and emission-analyzed heat sources.

\begin{tabular}{|c|c|c|c|c|c|c|c|}
\hline Type of the heat source & Coal boiler & $\begin{array}{c}\text { Coal } \\
\text { boiler with } \\
\text { feeder }\end{array}$ & Gas boiler & Oil boiler & Heat pump & $\begin{array}{l}\text { Biomass } \\
\text { boiler }\end{array}$ & $\begin{array}{c}\text { Coal boiler with } \\
\text { feeder and solar } \\
\text { collector }\end{array}$ \\
\hline The fuel & $\begin{array}{l}\text { Coal different } \\
\text { assortment }\end{array}$ & Coal peas & Natural gas & Fuel oil & Electricity & Biomass & Coal peas \\
\hline $\begin{array}{c}\text { The energy efficiency of the } \\
\text { heat source }(\%)\end{array}$ & 70 & 82 & 94 & 92 & 420 & 85 & 82 \\
\hline $\begin{array}{l}\text { The parameters of fuel } \\
\qquad \mathrm{MJ} / \mathrm{kg}\end{array}$ & 24 & 26 & 42.8 & 42.8 & & 12 & 26 \\
\hline Fuel consumption & $\begin{array}{c}7.3 \\
(\mathrm{Mg} / \text { year }) \\
\end{array}$ & $\begin{array}{c}5.7 \\
(\mathrm{Mg} / \text { year }) \\
\end{array}$ & $\begin{array}{c}3629.5 \\
\left(\mathrm{~m}^{3} / \text { year }\right)\end{array}$ & $\begin{array}{c}3708.4 \\
(\mathrm{~kg} / \text { year })\end{array}$ & $\begin{array}{c}8033.0 \\
{[\mathrm{kWh} / \text { year }]}\end{array}$ & $\begin{array}{c}11.9 \\
{[\mathrm{Mg} / \mathrm{year}]}\end{array}$ & $\begin{array}{c}5.4 \\
{[\mathrm{Mg} / \text { year }]}\end{array}$ \\
\hline Cost of fuel (EUR) & 956 & 882 & 1469 & 4150 & 861 & 708 & 836 \\
\hline $\begin{array}{l}\text { Total cost of operation } \\
\text { (EUR) }\end{array}$ & 995 & 913 & 1505 & 4150 & 861 & 772 & 865 \\
\hline $\begin{array}{l}\text { Save/increase in operating } \\
\text { costs (EUR /year) }\end{array}$ & - & -82 & -510 & -3155 & 134 & 223 & 130 \\
\hline $\begin{array}{l}\text { The total emission of } \\
\text { pollutants }(\mathrm{kg} / \text { year })\end{array}$ & 604 & 423 & 1.03 & 131.08 & 0 & 131.08 & 399 \\
\hline $\mathrm{CO}_{2}$ emissions (kg/year) & 14600 & 11400 & 7128 & 7098 & 0 & 0 & 10800 \\
\hline CO emissions (kg/year) & 329 & 257 & 0.98 & 3 & 0 & 78.72 & 243 \\
\hline $\mathrm{SO}_{2}$ emissions (kg/year) & 93 & 46 & 0.01 & 82 & 0 & 2.38 & 43 \\
\hline $\mathrm{NO}_{\mathrm{x}}$ emissions $(\mathrm{kg} /$ year $)$ & 7 & 6 & 0.00 & 22 & 0 & 8.33 & 5 \\
\hline Emissions of dust (kg/year) & 175 & 114 & 0.04 & 8 & 0 & 41.65 & 108 \\
\hline $\begin{array}{l}\text { Ecological effect in } \\
\text { relation to the building } \\
\text { representative: } \\
\text { - reduction of emissions of } \\
\text { pollutants ( } \mathrm{kg} / \text { year), } \\
\text { - reduce carbon dioxide } \\
\text { emissions ( } \mathrm{kg} / \text { year) }\end{array}$ & $\begin{array}{l}X \\
X\end{array}$ & $\begin{array}{l}181 \\
3200\end{array}$ & $\begin{array}{l}603 \\
7472\end{array}$ & $\begin{array}{l}489 \\
7502\end{array}$ & $\begin{array}{c}604 \\
14600\end{array}$ & $\begin{array}{c}473 \\
14600\end{array}$ & $\begin{array}{l}231 \\
3800\end{array}$ \\
\hline $\begin{array}{c}\text { LCA value of the } \\
\text { environmental impact } \\
\text { of heat sources (Pt/year) }\end{array}$ & 264 & 150 & 16.4 & 58.5 & 193 & 12.6 & 139 \\
\hline
\end{tabular}

Source: [45] 
without environmental impact, which took place during the production of boilers and environmental impacts associated with the formation of infrastructure needed to transport and/or store fuel. A functional unit, that is the unit adopted in the study, which is the quantitative effect of the production system, is a demand for thermal energy in $\mathrm{kWh}$ of the considered building, representative within a year. For calculations we used the eco-indicator 99 assessment, which allows for the presentation of the results of impact in relation to the 11 impact categories and 3 damage categories [43].

Table 3 shows the operating and emission parameters of 8 analysed heat sources together with the results of LCA. After analysing Low-Carbon Economy Plans in communities locating within the Lubuskie Voivodeship, it should be noted that the parameters of analysed heat sources are close to the household boilers located in Lubuskie. On the other hand, developing Low-Carbon Economy Plans allows municipalities to obtain EU funds in 2014-2020. Thanks to EU funds, municipalities will be able to carry out projects involving thermal modernization of buildings, implementing renewable energy sources, and carrying out activities aimed at upgrading public transport, which will reduce emissions. The second column of Table 3 corresponds to the most pervasive case, in the old individual heat sources. The third and eighth columns show a situation that used coal boilers with the feeding of a newer type from oldtype boilers from the second column. Although they are economical and easy to use, they are not sufficiently environmentally friendly, as evidenced by the worst result, which is the highest impact on the environment (the result is shown in the last row of the table). Analysing the results contained in the last column of Table 3 shows that coal-fired boilers, even if they are supported by solar collectors, do not guarantee an environmental effect that could be acceptable. Although the lowest impact on the environment is attributed to boilers fuelled by natural gas and biomass (columns 4 and 7), the biomass is preferable from the economic point of view [44-46]. In contrast, it should be emphasized that the combustion of biomass in the boilers without an effective capture dust installation can contribute to excessive concentrations of PM10, especially if a large number of this type of boiler equipment was located in one place [47-50]. It should be highlighted that in Lubuskie there is good access to biomass in the local market, which means that it does not have to be transported over long distances, which would significantly reduce the environmental effect of the use of this fuel for heating purposes [51-55].

\section{Conclusions}

These activities, although they must be gradually implemented, will meet the resistance of residents along with a strong mining lobby in Poland. The reason for this is the fact that coal is an energy resource extracted in Poland and its extraction can employ tens of thousands of miners, not to mention companies that operate in the immediate vicinity of the mining industry. It should be noted that most EU coal miners work in Poland.

Previous attempts to reduce the combustion of coal in Poland have encountered obstacles. Low emission in the Polish legal system relating to the protection of the environment is not treated as a separate issue. Currently used legal instruments, which are aimed at limiting low emission, are often ineffective and do not sufficiently mitigate the impact of air pollution on the environment. A possibility for reducing the environmental impact of low emission is the so-called Anti-smog Act of 2015. Before the entry of the law into force, it was only possible to completely prohibit the use of certain fuels used during the heating of residential buildings. However, this was not an effective solution, which is reflected in the decision of the Regional Administrative Court in Krakow, which rescinded the anti-smog resolution of the Malopolska Regional Council, introducing in Krakow ban on the use of coal in domestic boilers from 1 January 2018. Only the Anti-smog Act allowed for the introduction of regulations limiting the negative impact of low emission on the environment. In Krakow under the Anti-smog Act there was introduced a resolution that imposes limits for boilers, fireplaces, and stoves, and it is effective from 1 September 2019. The Anti-smog Act allows local governments to specify types of fuel with which it will be possible to heat rooms and to set technical standards for boilers. The amendment to the Environmental Protection Law allows regional parliaments to determine the resolutions of the kind and quality of solid fuels that may be authorized. Regional parliaments can also pass a ban on the use of certain heating installations. It should be noted that Krakow is one of the most polluted cities in the EU, and despite it, the introduction of legal solutions that allow for reducing low emission was a problem.

\section{Acknowledgements}

This study was conducted and financed in the framework of the research project "Economic, ecological, and social aspects of low emission limitations in the Middle Odra" (grant No. 2015/19/D/HS4/00210) and "The state and prospects of the development of lowcarbon agriculture in Poland and the behaviour of agricultural producers" (grant No. 2016/21/D/HS4/00087 from the National Science Centre in Poland, SONATA program). 


\section{Conflict of Interest}

The authors declare no conflict of interest

\section{References}

1. VERSHININA K.Y., KUZNETSOV G.V., STRIZHAK P.A. Ignition Characteristics of Coal - Water Slurry Containing Petrochemicals Based on Coal of Varying Degrees of Metamorphism. Energy Fuels, 30 (8), 6808, 2016.

2. PONTAU P., HOU Y., Cai H., ZHEN Y., JIA X., CHIU A.S.F., XU M. Assessing land-use impacts by clean vehicle systems Resources. Conservation and Recycling, 95, 112, 2015.

3. FAMELI K.M., ASSIMAKOPOULOS V.D. Development of a road transport emission inventory for Greece and the Greater Athens Area: Effects of important parameters. Science of The Total Environment, 505, 770, 2015.

4. World Health Organization. Available online: http:// www.who.int/mediacentre/news/releases/2016/deathsattributable-to-unhealthy-environments/en/ (accessed on 10.10.17)

5. CETIN M., SEVIK H., ISINKARALAR K. Changes in the particulate matter and $\mathrm{CO}_{2}$ concentrations based on the time and weather conditions: the case of Kastamonu. Oxidation Communications, 40 (1-II), 477, 2017.

6. CETIN M., SEVIK H. Change of air quality in Kastamonu city in terms of particulate matter and $\mathrm{CO}_{2}$ amount. Oxidation Communications 39, (4-II), 3394, 2016.

7. CETIN M., SEVIK H. Measuring the Impact of Selected Plants on Indoor $\mathrm{CO}_{2}$ Concentrations. Polish Journal of Environmental Studies, 25 (3), 973, 2016.

8. SEVIK H., CETIN M. Effects of Water Stress on Seed Germination for Select Landscape Plants. Polish Journal of Environmental Studies 24 (2), 689, 2015.

9. BELL M.L., DAVIS D.L., FLETCHER T. A retrospective assessment of mortality from the London smog episode of 1952 the role of influenza and pollution. Environmental Health Perspectives, 112 (1), 6, 2004.

10. KHIDR K.I., ELDRAINY Y.A., EL-Kassaby M.M. Towards lower gas turbine emissions: Flameless distributed combustion. Renewable and Sustainable Energy Reviews, 67, 1237, 2017

11. TKACZYK W., KOZIEŁ A., MIKOŁAJUK H. Energy consumption in households in 2012, Główny Urząd Statystyczny, Warszawa, pp. 64, 2014 [In Polish].

12. DYLEWSKI R., ADAMCZYK J. Study on ecological costeffectiveness for the thermal insulation of building external vertical walls in Poland. Journal of Cleaner Production, 133, 467, 2016.

13. DYLEWSKI R., ADAMCZYK J. The environmental impacts of thermal insulation of buildings including the categories of damage: A Polish case study. Journal of Cleaner Production, 137, 878, 2016.

14. Urząd Statystyczny w Zielonej Górze. Available online: http://zielonagora.stat.gov.pl (accessed on 12.09.17) [In Polish].

15. Statistical Yearbook of Poland, Główny Urząd Statystyczny, Warszawa, pp. 37, 2013 [In Polish].

16. Agricultural Market Agency. Available online: www.arr. gov.pl (accessed on 10.10.17)

17. The Statistical Yearbook of Voivodeships, Główny Urząd Statystyczny, Warszawa, pp. 546, 2012 [In Polish].
18. SUSEK P. The state of the environment in the Lubuskie Voivodeship in 2013-2014, Wojewódzki Inspektorat Ochrony Środowiska w Zielonej Górze, Zielona Góra, pp. 45, 2015 [In Polish].

19. National balance of $\mathrm{SO}_{2}, \mathrm{NO}_{x}, \mathrm{CO}, \mathrm{NH}_{3}, \mathrm{NMVOC}$, particulates, HMs and POPs emission in 2013-2014 in SNAP and NFR classification, Instytut Ochrony Środowiska - Państwowy Instytut Badawczy, Warszawa, pp. 13, 2016 [In Polish].

20. ADAMCZYK J., PIWOWAR A., DZIKUĆ M. Air protection programmes in Poland in the context of the low emission. Environmental Science and Pollution Research, 24 (19) 16316, 2017.

21. Rocznik Statystyczny Rzeczpospolitej Polskiej, Główny Urząd Statystyczny, Warszawa, pp. 70, 2015 [In Polish].

22. Statistical Yearbook of Poland, Główny Urząd Statystyczny, Warszawa, pp. 482, 2015 [In Polish].

23. KRAUZE-BIERNACZYK M., CZARNIECKA P., KOCIOŁEK E. The annual air quality assessment in Lubuskie, Wojewódzki Inspektorat Ochrony Środowiska w Zielonej Górze, Zielona Góra, 33, 2016 [In Polish].

24. DIMITRIOU K., KASSOMENOS P. A study on the reconstitution of daily PM10 and PM2.5 levels in Paris with a multivariate linear regression model. Atmospheric Environment, 98, 648, 2014.

25. DIMITRIOU K., KASSOMENOS P. Decomposing the profile of PM in two low polluted German cities Mapping of air mass residence time, focusing on potential long range transport impacts. Environmental Pollution, 190, 91, 2014.

26. LARGERON Y., STAQUET C. Persistent inversion dynamics and wintertime PM10 air pollution in Alpine valleys. Atmospheric Environment,135, 92, 2016.

27. The Environmental Protection Law of 10 September 2015 r., Dz. U. z 2015 r. poz. 1593 [In Polish].

28. Regional Operational Programme - Lubuskie 2014-2020. Available online: http://rpo.lubuskie.pl/ (accessed on 12.10.17) [In Polish].

29. WĘDZIK A., SIEWIERSKI T., SZYPOWSKI M. Green certificates market in Poland - The sources of crisis. Renewable and Sustainable Energy Reviews, 75, 490, 2017.

30. LOCHNO A. Program update for air protection zone of the city of Zielona Góra due to exceeding the target value of benzo(a)pyrene in PM10, Wojewódzki Fundusz Ochrony Środowiska i Gospodarki Wodnej w Zielonej Górze, Zielona Góra, pp. 72, 2015 [In Polish].

31. LELEK Ł., KULCZYCKA J., LEWANDOWSKA A., ZARĘBSKA J. Life cycle assessment of energy generation in Poland. International Journal of Life Cycle Assessment, 21 (1), 1, 2016.

32. LEWANDOWSKA A., NOSKOWIAK A., PAJCHROWSKI G., ZARĘBSKA J. Between full LCA and energy certification methodology - a comparison of six methodological variants of buildings environmental assessment. International Journal of Life Cycle Assessment, 20 (1), 9, 2015.

33. ZUO J., PULLENC S., RAMEEZDEEN R., BENNETTS H., WANG Y., MAO G., ZHOU Z., DU H., DUAN H. Green building evaluation from a life-cycle perspective in Australia: A critical review. Renewable and Sustainable Energy Reviews, 70, 358, 2017.

34. CUCCHIELLA F., GASTALDI M., TROSINI M., Investments and cleaner energy production: A portfolio analysis in the Italian electricity market. Journal of Cleaner Production, 142 (1), 121, 2017. 
35. ERIKSSON O., FINNVEDEN G., EKVALL T., BJÖRKLUND A. Life cycle assessment of fuels for district heating: a comparison of waste incineration, biomass- and natural gas combustion. Energy Policy, 35 (2), 1346, 2007.

36. DZIKUĆ M., PIWOWAR A. Life cycle assessment as an eco-management tool within the power industry. Polish Journal of Environmental Studies, 24 (6), 2381, 2015.

37. BURCHART-KOROL D., KOROL J., CZAPLICKAKOLARZ K. Life cycle assessment of heat production from underground coal gasification. The International Journal of Life Cycle Assessment, 21 (10), 1391, 2016.

38. ISO. Environmental management - life cycle assessment - principles and framework. International Standard ISO 14040:2006. ISO; 2006a.

39. ISO. Environmental management - life cycleassessment - requirements and guidelines. International Standard ISO 14044:2006. ISO; 2006b.

40. DZIKUĆ M., DZIKUĆ M., SINIČÁKOVÁ M. The social aspects of low emission management in the Nowa Sól district. Management, 21 (1), 237, 2017.

41. DZIKUĆ M., PIWOWAR A. Ecological and economic aspects of electric energy production using the biomass co-firing method: The case of Poland. Renewable and Sustainable Energy Reviews, 55, 856, 2016.

42. DZIKUĆ M. Applying the life cycle assessment method to ananalysis of the environmental impact of heat generation. International Journal of Applied Mechanics and Engineering, 18 (4), 1275, 2013.

43. DZIKUĆ M., URBAN S. The environmental impact assessment of thermal power generation in selected power plants. Energetyka. Problemy Energetyki i Gospodarki Paliwowo-Energetycznej, 5, 295, 2014 [In Polish].

44. MUNOZ E., VARGAS S., NAVIA R. Environmental and ecnomic analysis of residual woody biomass transport for energetic use in Chile. International Journal of Life Cycle Assessment, 20 (7), 1033, 2015.

45. DZIKUĆ M., J. ADAMCZYK. The ecological and economic aspects of a low emission limitation: A case study for Poland. International Journal of Life Cycle Assessment, 20 (2), 217, 2015.
46. DZIKUĆ M., ŁASIŃSKI K. Technical and economic aspects of biomass co-firing in coal-fired boilers. International Journal of Applied Mechanics and Engineering, 19 (4), 849, 2014.

47. RAFAEL S., TARELHO L., MONTEIRO A., SÁ E., MIRANDA A.I., BORREGO C., LOPES M. Impact of forest biomass residues to the energy supply chain on regional air quality. Science of The Total Environment, $\mathbf{5 0 5}, 640,2015$.

48. KRZYŻANIAK M., STOLARSKI M.J., NIKSA D., TWORKOWSKI J., SZCZUKOWSKI S. Effect of storage methods on willow chips quality. Biomass and Bioenergy, 92, 61, 2016.

49. CIEŚLIKA M., DACH J., LEWICKI A., SMURZYŃSKA A., JANCZAK D., PAWLICKA-KACZOROWSKA J., BONIECKI P., CYPLIK P., CZEKAŁA W., JÓŹWIAKOWSKI K. Methane fermentation of the maize straw silage under meso- and thermophilic conditions. Energy, 115 (2), 1495, 2016.

50. HALDER P.K., PAUL N., JOARDDER M.U.H., KHAN M.Z.H., SARKER M. Feasibility analysis of implementing anaerobic digestion as a potential energy source in Bangladesh. Renewable and Sustainable Energy Reviews, 65, 124, 2016.

51. JOSELIN HERBERT G.M., UNNI KRISHNAN A. Quantifying environmental performance of biomass energy. Renewable and Sustainable Energy Reviews, 59, 292, 2016.

52. NAKOMCIC-SMARAGDAKIS B., CEPIC Z., DRAGUTINOVIC N. Analysis of solid biomass energy potential in Autonomous Province of Vojvodina. Renewable and Sustainable Energy Reviews, 57, 186, 2016.

53. PIWOWAR A., DZIKUĆ M., ADAMCZYK J. Agricultural biogas plants in Poland - selected technological, market and environmental aspects. Renewable and Sustainable Energy Reviews, 58, 69, 2016.

54. DZIKUĆ M, ADAMCZYK J., PIWOWAR A. Problems associated with the emissions limitations from road transport in the Lubuskie Province (Poland). Atmospheric Environment, 160, 1, 2017.

55. DZIKUĆ M. Problems associated with the low emission limitation in Zielona Góra (Poland): Prospects and challenges. Journal of Cleaner Production, 166, 81, 2017. 